International Journal of STEM Education for Sustainability, Vol.1, No.1, 2021, pp. 53-59

e-ISSN 2798-5091. DOI. 10.53889/ijses.v1i1.8

\title{
Implementation of Talking Stick Method on Acid-Base Concepts to Improve Students' Critical Thinking Skills
}

\author{
Submitted 4 June 2021, Revised 25 July 2021, Accepted 25 July 2021 \\ St Fatimah Azzahra ${ }^{1 *}$, Nova Irawati Simatupang ${ }^{2}$ \\ ${ }^{1,2}$ Faculty of Teacher Training and Education, Universitas Kristen Indonesia, Jakarta, Indonesia
}

Corresponding email: *siti@uki.ac.id

\begin{abstract}
This study aimed to improve the critical thinking skills of class XI high school on acid base material in the 2018/2019 using the talking stick method. This research is a classroom action research conducted in two cycles. Each cycle consists of planning, implementation, observation and reflection so that this study describes planning, activities and improving critical thinking skills of high school of class XI. The subjects of this research is all students of grade XI in one of the South Tangerang high schools in Indonesia which consisted of 33 students. Data collection techniques in this study were using essay tests, observation sheets, teacher activities, student activities, field notes and interviews. The results of this study indicate that students' critical thinking skills increase using the talking stick method seen from the student ability to answer questions, express opinions, respond to friend opinions and consider sources. Critical thinking skills has increased, in the first cycle that is equal to $21.20 \%$ while in the second cycle is $90.90 \%$. It can be concluded that the use of the talking stick method can improve the critical thinking skills of class IX high school in acid base material.
\end{abstract}

Keywords: action research, critical thinking skills, talking stick

\section{INTRODUCTION}

Learning is a process of finding experience that requires a complex process (Satrianawati, 2018). So that in learning activities in the classroom students must play an active role in the learning process. The activeness of students in the classroom can improve students' thinking abilities. Anwar and Yanti (2014) stated that in reality there were still many students who were not active in the classroom during the learning process. Student activity is an activity or activities that can bring change towards a better direction because of interactions with one another (Megawati, 2012). In addition to bringing change towards the better, student activity in the learning process can also improve students' thinking skills both critical thinking skills and creative thinking skills.

Critical thinking skills are needed to improve understanding of chemical concepts, especially in acid-base material (Muchtar and Harizal, 2012). The concept of acid base solution is a basic concept of chemistry. Because chemistry learning is not only with the activity of solving problems in accordance with the example problems given by the teacher in the classroom, but it needs to actively involve students in learning activities in the classroom. Lathifa, Suhadi, and Endang (2015) there are still many students who have problems in understanding the concept of acid base. These problem include understanding students' concepts, errors in using symbols, mathematical formulas, neglect of concepts, initial concepts not in accordance with the scientific. The results of the study indicate that $17 \%$ of students 
International Journal of STEM Education for Sustainability, Vol.1, No.1, 2021, pp. 53-59 e-ISSN 2798-5091. DOI. 10.53889/ijses.v1i1.8

understand the concept, $61 \%$ of student misconception and $22 \%$ of student do not understand the concept.

Muchtar and Harizal (2012) states that the cause of students' low understanding of the concept of acid-base is caused by the lack of ability to solve problems, ignore contexts, and generalize problems without understanding the theory behind them. Besides the problems also arise from the initial concept of students who are not in accordance with scientific findings and the low level of student activity in learning activities. Increased student activity in the learning process is expected to develop student scientific attitudes that result in good learning outcomes and students' critical thinking skills. One learning that can train students to be active in the learning process in class is learning using the talking stick method. Talking stick learning is learning that can test the readiness of students in learning, train students to understand the material quickly and encourage students to be active in learning (Shoimin, 2014). Learning using the talking stick method is learning that trains students in speaking, creates a pleasant learning atmosphere, makes students active when learning takes place so that it indirectly also trains students' critical thinking skills. Talking stick learning should also use musical accompaniment when learning is intended to eliminate the tension in students, giving enthusiasm to students and students are motivated during the learning process. Based on the background, the purpose of this research is to see the improvement of critical thinking skills using the talking stick method.

\section{METHOD}

The research method in this study is cyclic research that refers to classroom action research that is research that refers to four stages. The first stage is the planning stage, implementation stage of the action, observation and the fourth stage is the reflection stage (Arifin, 2012). This cyclical study was carried out at one of the high schools in Shouth Tangerang City with the sample of the study being 33 students grade XI IPA of 18 female students and 15 male students in the academic year 2018/2019. Research activities at the planning stage in which the researcher observes the state of grade XI when following the chemistry learning process in the classroom. With this the researcher will find the shortcoming of the class.

The planning stage, the researcher makes preparations that is making an implementation plan using the talking stick method and preparing questions related to acid-base material. In the planning stage, the researcher also made an observation sheet implementing the learning process of talking stick with the aim to see the activities of the teacher and students using the learning process using the talking stick method as well as seeing students' critical thinking 
International Journal of STEM Education for Sustainability, Vol.1, No.1, 2021, pp. 53-59 e-ISSN 2798-5091. DOI. 10.53889/ijses.v1i1.8

skills when using talking stick learning. As for learning using the talking stick method, the teacher must prepare a stick, first the teacher prepares acid-base material then the teacher gives the opportunity to students to read and study acid-base material, then the teacher gives savings to students to read and learn acid-base material. After students learn acid-base material, the teacher gives questions in the form of basic problems that the teacher has prepared before learning. This activity is carried out until all students or $70 \%$ of students get a part to answer the questions given by the teacher, then the teacher gives a conclusion after that the teacher evaluates the critical thinking skills of students at the end of learning.

After the learning tool has been completed, the researcher makes an evaluation tool, the evaluation used in this study is an instrument of critical thinking skills with five items of acidbase material essay test in each learning cycle with the intention to see an increase in students' critical thinking skills on acidic base material. Critical thinking indicators developed in this study are identifying or focusing on possible response criteria, identifying conclusions, identifying the stated reasons for looking for the structure of an opinion or argument, critical thinking skills asking and answering.

The implementation phase is the researchers carry out the learning process by using the talking stick method in accordance with the learning implementation plan that researchers have designed in the planning stage. In learning to use the talking stick method the teacher needs to do is learn the learning objectives, the teacher explains briefly to students before the talking stick learning activity is carried out. After the explanation is done, the teacher asks students to read the acid-base material individually or group by adding more references. Then the teacher asks students to close all references that are read by students and prepare help and songs to be used as a medium in learning talking sticks the give questions to students who get a stick when the song stops. The questions given by the teacher relate to acid-base material and the teacher prepares as many questions as possible.

The observation phase in each cycle is carried out by the researcher during the learning process using the talking stick method an acid-base material. Observations that researchers do is observing the activities of teachers in accordance or not with the learning plan at has been made and conclusions related to the material provided by the teacher at the teacher at the end of learning. Observation in this study also looked at student activities in understanding acidbase material, references students learned, students enthusiasm in participating in learning activities using the talking stick method, how to move the stick, how to answer questions from the teacher and how students issued opinions. 
International Journal of STEM Education for Sustainability, Vol.1, No.1, 2021, pp. 53-59 e-ISSN 2798-5091. DOI. 10.53889/ijses.v1i1.8

The reflection stage in this study is to analyze the processes that have taken place in the learning activities using the talking stick method or the observations obtained at the observation stage. The reflection phase aims to determine the problems the problems that arise during the learning implementer using the talking stick method with acid-base material, in addition to seeing deficiencies that occur during the implementation process. The results of the reflections by the researchers are then used as a reference for planning the next cycle of this study.

The data generated in this study are quantitative data obtained from the results of student critical thinking skills tests. Critical thinking skills tests conducted in this study to measure critical thinking skills using the talking stick method on acid-base material. The critical thinking skills test in learning is used as the success of each cycle of action. The data obtained were obtained from individual students critical thinking skills test data collection at the end of the learning process in each cycle to obtain data about increasing students critical thinking skills on acid-base material obtained by students while the data analysis techniques used in this study obtained from the results of each cycle is to reduce data, present data and draw conclusions.

\section{RESULTS AND DISCUSSION}

This research is a classroom action research conducted by researchers as much as two cycles on acid-base material with learning using the talking stick method in one of South Tangerang City high schools. The sample in this research was grade XI. Researchers prepare learning tools ranging from making syllabus related to acid-base material, learning implementation plans using the talking stick method on acid-base material, making questions or questions in accordance with acid-base material, making critical thinking skills instruments. The instrument of critical thinking skills in this research was a five point essay shaped instrument that was in accordance with Ennis's critical thinking skills indicator. This research instrument, the researcher used as a measure to find out the improvement in critical thinking skills of students of grade XI in acid-base material. Before the instrument tool, the researcher first conducts the construct validation test first.

In the implementation of learning using the talking stick method on acid-base material in each cycle carried out in two meetings, namely carried out in $4 \times 45$ minutes. From the results obtained, student critical thinking skills in the first cycle with five item essay tests critical thinking skills about acid-base theory through talking stick learning. In the first cycle the average critical thinking skills that is equal to $21,20 \%$, seen from the average first cycle can be concluded that the first cycle is still unsuccessful because the percentage of the average value 
International Journal of STEM Education for Sustainability, Vol.1, No.1, 2021, pp. 53-59 e-ISSN 2798-5091. DOI. 10.53889/ijses.v1i1.8

is still low and has not reached $80 \%$ who have critical thinking skills in above or equal to 75 . So this study was decide to process to second cycle.

The findings during the learning process take place or the results of observations in the implementation of first cycle used as a reflection to improve learning in second cycle. In first cycle, students' activities in understanding acid-base material are still low, there are still many students who study the material individually. In the first cycle, it was seen that students still did not understand the talking stick method so there were still many students who did not answer the question given by the teacher and more of the students gave opinions related to questions raised by the teacher. In the implementation of the first cycle students were seen not following the songs used by the teacher when learning took place and the selection of songs by the teacher was not a song that was liked by students. There are still many questions that are prepared by the teacher before learning has not been given to students so that there are $65 \%$ of students who have not gotten questions from the teacher.

From the results obtained in the first cycle of students' critical thinking skills is still incomplete, so this research continues in the second cycle. Second cycle conducted research continues on acid-base material. The average data of students' critical thinking skills is $90.90 \%$ and it can be said that the second cycle has been successful and learning is not continued to the third cycle. In the second cycle, students have begun to understand how to learn using the talking stick method, students have more understanding of the material in groups, students have begun to regularly give sticks to friends, students choose their own songs to use and $80 \%$ of students answer the questions given when learning activities with the talking stick method. The ability of students' critical thinking skills will further develop if the teacher increasingly practices students' thinking skills. Students' critical thinking skills will vary depending on the practice that is often given by the teacher (Fakhriyah, 2014).

In second cycle the material taught continues on strong basic acids, weak basic acids and the concept of determining $\mathrm{pH}$ and $\mathrm{pOH}$. In this second cycle students have begun to be skilled in determining references in accordance with the material to be studied, students are already skilled to work together in understanding the material and students have begun to issue a stopper in accordance with the material being discussed in class. Learning using this talking stick method can make students active in the classroom, starting from the stabilization of the material to be discussed, moving the stick when the song is playing, participating in singing, answering questions given by the teacher and students have started to be able to draw conclusions when the end of learning. 
International Journal of STEM Education for Sustainability, Vol.1, No.1, 2021, pp. 53-59 e-ISSN 2798-5091. DOI. 10.53889/ijses.v1i1.8

From the results of the first cycle and the second cycle obtained an average increase in students' critical thinking skills. This shows that learning using the talking stick method can improve students' critical thinking skills. This is because that learning using the talking stick method actively involves students when the learning process in the classroom takes place. In talking stick learning students are given the opportunity to understand the material in depth in groups and individually with various references. Students are given the opportunity to choose their own songs in accordance with the wishes of students so that all students can follow the rhythm and participate in singing songs. By using this talking stick method all students have the same speaking rights given in turns or in turn. So this learning creates a pleasant learning atmosphere and makes students active in learning activities. Thus it can be said that learning using the talking stick method can improve the ability of critical thinking of grade XI on acidbase material in the 2018/2019 and can increase student activity in the learning process.

\section{CONCLUSION}

Based on the results and discussion above, it can be concluded that the first cycle has an average percentage of students' critical thinking skills with learning using the talking stick method of $21.20 \%$, while in the second cycle the average of students' critical thinking skills increases to $90.90 \%$ and can be said to be complete in second cycle.

\section{REFERENCES}

Anwar, K., and Yanti, N. (2014). Meningkatkan kreativitas belajar siswa menggunakan model cooperative scipt dalam pembelajaran IPA di kelas IV SD N. Citra Rakyat: 2

Arifin, Z. (2012). Penelitian Pendidikan. Bandung: Rosda Karya

Fakhriyah, F. (2014). Penerapan problem based learning dalam upaya mengembangkan kemampuan berpikir kritis mahasiswa. Jurnal Pendidikan IPA Indonesia. Vol.3. No.1

Lathifa, U., Suhadi, I., and Endang, B. (2015). Identifikasi kesalahan konsep larutan asam basa dengan menggunakan teknik certainty of response index (CRI) termodifikasi. Seminar Nasional Pendidikan Sains UKSW

Megawati, S. (2012). Model pembelajaran kooperatif tipe team assited individualization (TAI) dalam meningkatkan keaktifan siswa dan hasil belajar akutansi siswa kelas XI. Jurnal Pendidikan Akutansi Indonesia 10 (1): 163

Muchtar, Z., and Harizal. (2012). Analyzing of students' misconceptions on acid-base chemistry at senior higt school in medan. Journal of education and practice. Vol.3:65

Satrianawati. (2018). Media dan sumber belajar. Yogyakarta: Deepublish 
International Journal of STEM Education for Sustainability, Vol.1, No.1, 2021, pp. 53-59 e-ISSN 2798-5091. DOI. 10.53889/ijses.v1i1.8

Shoimin, A. (2014). 68 Model Pembelajaran Inovatif Dalam Kurikulum 2013. Yogyakarta: ArRuzz Media 